See discussions, stats, and author profiles for this publication at: https://www.researchgate.net/publication/263672610

\title{
Dual Allegiances? Immigrants' Attitudes toward Immigration
}

Article in The Journal of Politics · January 2015

DOI: $10.1086 / 678388$

CITATIONS

READS

10

258

2 authors:

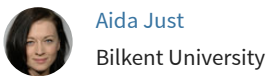

17 PUBLICATIONS 297 CITATIONS

SEE PROFILE

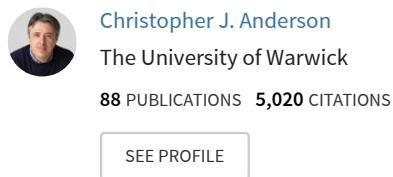




\title{
Dual Allegiances? Immigrants' Attitudes toward Immigration
}

\author{
Aida Just, Bilkent University \\ Christopher J. Anderson, Cornell University and London School of Economics
}

This article develops a model of immigrants' attitudes towards immigration. We focus on two competing motivations to explain these attitudes: while kinship, solidarity, and shared experiences with other immigrants should lead to more favorable attitudes towards immigration, formal integration into a new society may create a new allegiance to the host country that produces more critical views toward immigration. Using the European Social Survey (ESS) 1-5 data collected 2002-11 in 18 West European democracies, coarsened exact matching (CEM), and multilevel estimation techniques, our analyses reveal that foreigners support immigration more than natives. However, newcomers who have acquired citizenship in their host countries are more skeptical about the consequences of immigration and admitting new arrivals than noncitizen immigrants. This negative relationship between citizenship and support for immigration is particularly pronounced among those who are dissatisfied with their host country's macroeconomy.

Zwei Seelen wohnen, ach, in meiner Brust. Die eine will sich von der andern trennen. ${ }^{1}$

-Johann Wolfgang von Goethe (Faust)

F or over two decades, Europe has been struggling with the advent of global migration. Since the end of the Cold War, Europe's stock of immigrant-born populations has increased by almost 50\%, reaching 47.6 million people across the European continent (World Bank 2013). ${ }^{2}$ Literally from all over the world, they comprise between less than 5\% in Bulgaria, Romania, Poland, or Finland, to more than $15 \%$ of the population in Austria, Ireland, Switzerland, and Luxembourg. Notably, a number of European countries currently host immigrant populations whose shares are as high as or higher than those found in traditional immigration countries such as the United States. ${ }^{3}$ In a reversal from earlier centuries, Europe clearly has become a continent of immigration, with net gains in population primarily driven by increasing numbers of new arrivals (e.g., Franchino 2009).

The exclusion or insufficient inclusion of large populations of foreign nationals into socioeconomic and political spheres have raised questions about the commitment of some receiving countries to uphold liberal democratic values of equal treatment (Freeman 1995; Joppke 1998) and thus have challenged governments to contend with the practicalities of both accepting and absorbing immigrants. How migrants become successfully incorporated into their host societies has long been an important question for social scientists, and one that has taken on increasing relevance with the above-mentioned changes in the real world. Scholars have sought to understand why some countries' populations are more hospitable to foreigners, before and after they arrive, while others insist on protecting their shores from new arrivals.

Immigrants leave a mark on the societies they join; conversely, host countries shape the lives immigrants lead. While scholars have paid considerable attention to the former, they have shown less interest in the latter. That is,

Aida Just is an Assistant Professor of Political Science at Bilkent University, 06800 Ankara, Turkey. Christopher J. Anderson is a Professor of Government at Cornell University, Ithaca, NY 14853 and a Visiting Fellow at the London School of Economics.

1. This has been variously translated as "Two souls alas! are dwelling in my breast; And each is fain to leave its brother" or "In my bosom two spirits are contending, each attempting to separate from the other."

2. Supplementary material for this article is available at the "Supplements" link in the online edition. Data for replication will be available at https://www .researchgate.net/profile/Aida_Just/contributions?ev=prf_act upon publication.

3. In $2010,13.8 \%$ of the US population was foreign-born. 
scholars have sought to understand the impact that migration has on the attitudes and behaviors of native populations (e.g., Citrin et al. 1997; Fetzer 2000; Hainmueller and Hangartner 2013; Hainmueller and Hiscox 2007; Mayda 2006; McLaren 2003; Meuleman, Davidov, and Billiet 2009; Mughan and Paxton 2006; Semyonov, Rijman, and Gorodzeisky 2008; Sides and Citrin 2007; Sniderman, Hagendoorn, and Prior 2004) and immigrant admission and incorporation policies in Europe and elsewhere (e.g., Brubaker 1992; Hix and Noury 2007; Howard 2009; Jones-Correa 2001; Money 1999; Weil 2001). In contrast, little cross-national research exists on what immigrants themselves think of immigration-for example, whether they oppose immigration less than natives do and whether some migrants are more accepting of newcomers than others. Moreover, we do not know much about the sources of such differences-if they do in fact exist-in contemporary democracies and whether they are due to varying individual experiences, formal integration into the host societies, or something else entirely. ${ }^{4}$ As a consequence, little is known about migrants' attitudes towards other immigrants and preferences in regulating international migration.

How immigrants view migration has both theoretical and empirical relevance. Politically, immigrants can be effective advocates on their own behalf and others like them, especially as their shares grow; but the extent to which newcomers can forge stable political alliances and participate in politics as a cohesive block depends on their attitudes towards one another and the issue of immigration more generally (Oliver and Wong 2003; Sonenshein 2003). Negative attitudes towards each other could not only undermine them as a unified political force but also make it easier for those opposed to immigration to argue that those who benefit from it do not prize it. Thus, understanding what immigrants think of immigration, whether their attitudes differ from natives and amongst themselves, and why, are important questions for researchers and policy makers alike.

Below, we examine immigrants' attitudes towards immigration and argue that they are shaped by two competing motivations: their kinship, solidarity, and shared experiences with other immigrants but also by allegiances to their host societies. The former should lead to more favorable attitudes

4. Existing research in this area focuses on immigrants (mostly Latinos) in the United States (Binder, Polinard, and Wrinkle 1997; Branton 2007; Hood, Morris, and Shirkey 1997; Miller, Polinard, and Wrinkle 1984; Polinard, Wrinkle, and de la Garza 1984; Sanchez and Masuoka 2010); for studies comparing attitudes of immigrants and natives with respect to policy issues beyond immigration, see Branton (2007) and Schildkraut (2013). about immigration; the latter may well produce the opposite effect. In particular, we hypothesize that the formal incorporation via citizenship is associated with a more critical stance toward immigration, as it produces an alignment with the attitudes of native populations. Moreover, we argue that citizenship acquisition increases individuals' sensitivity to the host country's economic situation when evaluating immigration.

We examine these propositions using the European Social Survey (ESS) 1-5 data collected 2002-11 in 18 West European democracies. Using coarsened exact matching (CEM) and multilevel estimation techniques, our analyses reveal that, while foreigners express more positive views about immigration than natives, newcomers who have acquired citizenship in their host countries are significantly less sanguine about immigration than noncitizen immigrants. Moreover, we find that the negative relationship between citizenship and support for immigration is particularly pronounced among those who are dissatisfied with their host country's macroeconomy.

Our study contributes to research on political incorporation and public opinion on immigration in several ways. On a theoretical level, we seek to extend the study of antiimmigrant opinion by going beyond the exclusive focus on natives and analyzing how immigrants perceive the consequences of immigration for their adopted homelands. Moreover, we highlight the complex role that formal political incorporation-citizenship-plays in shaping support for immigration among foreign-born individuals. Finally, our analysis goes beyond existing studies of one or a small number of countries or cities and puts arguments to a more extensive empirical test against a bigger sample of immigrants in a larger set of European nations with diverse immigrant populations. We proceed as follows: the next sections formulate and develop our argument; we then describe our data and measures, present our analyses and robustness tests along with a discussion of our findings, and finally conclude by offering suggestions for further research.

\section{KINSHIP, SOLIDARITY, AND COGNITIVE DISSONANCE AVOIDANCE}

Though migrants hail from many different nations, they all have gone through the process of moving to another countryan experience that may create a sense of solidarity and kinship with other migrants. Being a migrant means having been born into and having lived in a different political, economic, and social environment; it also means an experience of the physical and psychological uprooting and relocation, which often require considerable efforts in adjusting to a new environment as well as learning how to cope 
with the consequences of being an outsider and being different in one's adopted homeland. ${ }^{5}$

In addition to a sense of kinship and solidarity with other newcomers brought on by shared experiences of migration, classic theories of cognitive dissonance avoidance (e.g., Festinger 1957) would predict that individuals who made the choice to migrate themselves would evaluate that same choice made by others positively. These psychological processes along with understanding the difficulties and challenges that migration involves are bound to leave a mark. In particular, they should make foreign-born individuals more sympathetic toward other immigrants and their decision to relocate to another country and thus encourage foreigners to express more positive opinions toward immigration and other immigrants in comparison to native-born individuals.

\section{CITIZENSHIP}

In addition to differences between natives and immigrants in their support for immigration, we are interested in differences among immigrants themselves. Specifically, we ask whether the formal incorporation of newcomers into the political community via citizenship plays a role in shaping attitudes toward immigration among foreign-born individuals. We argue that citizenship aligns the attitudes of natives and newcomers, making foreign-born citizens less enthusiastic about immigration than foreigners who have not acquired citizenship in their host country.

We base this expectation on several empirical regularities that emerge from the literature about individuals' choice to become naturalized. While the acquisition of citizenship is surely the product of a complex set of conditions and considerations, many qualitative and quantitative studies have uncovered a consistent set of factors that predict citizenship acquisition. Specifically, naturalization has been linked to immigrants' cultural and economic assimilation, but also to their instrumental considerations, such as the desire to access important benefits and resources bestowed only on citizens (e.g., Bloemraad 2006; DeSipio 1987; Garcia 1981; Grebler 1966; Portes and Curtis 1987; see also Bueker 2005; Jones-Correa 1998, 2001; Wong and Pantoja 2009; Yang 1994).

This means that the acquisition of citizenship is a mark of self-selection into an identity-an expression of kinship with the host country rather than, or in addition to, the sending

5. In line with this perspective, several previous studies on Latino immigrants in the United States found that perceptions of linked fate or attachment to their ingroup are much stronger among foreign-born than among immigrants of later generations (e.g., Barreto and Pedraza 2009; Sanchez and Masuoka 2010). country-as well as a quest for access to a legal status that provides formal protections and material benefits (political rights, wider employment opportunities, welfare benefits, visa-free travel, protection against deportation, etc.). Both kinds of motivations would lead us to assume that the beliefs of foreigners who choose to naturalize are more similar to those of the majority group (native-born citizens). Thus, there are good reasons to expect that citizenship is associated with less enthusiasm for continued immigration and a more critical stance toward the consequences it may have for host societies.

\section{CONTINGENT EFFECTS OF CITIZENSHIP: THE ROLE OF ECONOMIC EVALUATIONS}

One key argument in existing research is that economic threat is a prime mover of anti-immigration attitudes among natives (e.g., Esses et al. 2001; Maio, Esses, and Bell 1994; Scheve and Slaughter 2001; Stephan et al. 2005). In addition to labor-market status and skills, personal economic circumstances-be they employment status, income, or tax burden - all have been assumed to shape opinion on immigration. Thus, anti-immigration sentiment has long been thought to find fertile ground among the unemployed, underemployed, and other constituencies that are struggling economically (Fetzer 2000). In addition, Citrin and collaborators (Citrin et al. 1997; Sides and Citrin 2007) have found that concerns about the state of the national economy are major determinants of anti-immigration sentiment (see also Hainmueller and Hopkins 2014). Taken together, these studies suggest that perceptions of economic threat should matter for people's opinions about immigration and that this threat is likely to manifest itself particularly strongly in socio-tropic ways.

In the same way that natives feel threatened by newcomers, foreigners may oppose the further influx of newcomers whose arrival might intensify competition for jobs, wages, and public services, or might threaten them economically in other ways. We argue, moreover, that such negative effects of economic threat are only amplified by the acquisition of citizenship. Psychologically, along with citizenship acquisition, a sense of kinship with one's adopted homeland may encourage foreigners to care more about their host society and the causes of its well-being. Instrumental considerations may play a role as well, particularly if newcomers are required to give up their former citizenship to obtain a new one, making return migration more difficult in case the economy in one's host country turns truly bad. Finally, since naturalized foreigners acquire the legal right to vote in national elections, they may become more attuned to electoral debates that often emphasize the links 
between the economy and immigration. In short, citizenship should enhance the negative effect of economic threat, such that immigrants who both have citizenship and feel that the economy of their host country is threatened will express some of the most negative attitudes about immigrants and immigration.

Taken together, then, we expect immigration attitudes among foreign-born individuals to be shaped by two competing considerations. On one hand, we expect them to express more positive views about immigration than natives by virtue of their own experiences, instrumental motivations, as well as a sense of solidarity and kinship with other immigrants. Thus:

Hypothesis 1: Foreign-born individuals should hold more positive views about immigration than nativeborn individuals.

While solidarity with other immigrants is likely to make foreign-born individuals more open to immigration, citizenship should exert the opposite effect. Put simply,

Hypothesis 2: Foreign-born citizens should express more negative views about immigration than foreignborn noncitizens.

Finally, the consequences of citizenship for immigration attitudes should at least in part be contingent on evaluations of the economic environment. Thus,

Hypothesis 3: The negative relationship between dissatisfaction with the economy and support for immigration should be particularly pronounced among foreign-born individuals who have acquired citizenship of their host country.

\section{DATA AND MEASURES}

The individual-level data analyzed below come from the European Social Survey (ESS) five-round cumulative file, 2002-11 (Jowell et al., 2007). The ESS project is known for its high standards of methodological rigor in survey design and cross-national data collection (Kittilson 2009). ${ }^{6}$ Moreover, this collaborative project is the only set of cross-national sur-

6. The ESS relies on strict random sampling of individuals aged 15 or older regardless of nationality, citizenship, language, or legal status to ensure representativeness of national populations. The data have been shown to contain representative samples of foreign-born populations as well (for details, see Just and Anderson 2012). veys that include questions designed specifically for foreignborn respondents and ask people about their citizenship status, attitudes towards immigration, economic evaluations, and sociodemographic characteristics. In addition, it is the only set of surveys that present these questions in identical format across a broad range of countries. The relevant survey items were available for 18 West European democracies: Austria, Belgium, Cyprus, Germany, Denmark, Finland, France, Great Britain, Greece, Ireland, Italy, Luxembourg, the Netherlands, Norway, Portugal, Spain, Sweden, and Switzerland.

\section{Dependent Variables}

Consistent with previous research (Citrin and Sides 2008; Sides and Citrin 2007), we rely on two dependent variables to measure people's attitudes towards immigration: the perceived consequences of immigration and beliefs about the appropriate level of immigration in one's country. First, we created an index of the perceived consequences of immigration with the help of three ESS items designed to capture respondents' opinions on whether immigration is bad or good for their country's economy, whether immigrants undermine or enrich the country's cultural life, and whether immigrants make the country a worse or better place to live. Using answers to these questions, we calculated an average for each respondent; the resulting index ranges from 0 to 10 , with higher values representing more positive evaluations of immigration. ${ }^{7}$

Our second dependent variable-the preferred level of immigration-is similarly based on three survey items. The ESS asked respondents to what extent their host country should allow people of the same race or ethnicity as most people in their country, people of a different race or ethnicity, and finally, people from poorer countries outside Europe to come and live there. Using the response categories "allow none," "allow a few," "allow some," and "allow many" for each of these questions, we created an index, which represents an average value for each individual respondent. The variable was recoded so that it ranges from 0 to 10, with higher values indicating more support for immigration. ${ }^{8}$

\section{Independent Variables}

To identify foreign-born respondents in our sample and to distinguish between citizens and noncitizens among them, we relied on two ESS questions "Were you born in [country]?" and "Are you a citizen of [country]?" Both are di-

7. The three items scale very well, with a Cronbach's alpha of .79 among foreign-born respondents.

8. Cronbach's alpha is .87 among foreign-born respondents. 
chotomous, with 1 indicating a positive response, and zero a negative one. ${ }^{9}$ Pooling the data across 18 West European countries generated a sample of 12,689 foreign-born respondents (8.30\% of all respondents); of these, $46.04 \%$ are citizens and 53.96\% are noncitizens of their host country.

In addition to testing the direct effects of citizenship on immigration attitudes among foreign-born individuals, we sought to examine whether citizenship interacts with people's evaluations of the health of macroeconomy in their host country. The latter was measured using the following ESS question: "On the whole how satisfied are you with the present state of the economy in [country]?" To facilitate the interpretation of our results, the original variable, ranging from 0 to 10 , was recoded so that higher values indicate more dissatisfaction with economy. ${ }^{10}$

\section{Control Variables}

To isolate the direct and contingent effects of citizenship on foreigners' attitudes towards new arrivals, our estimation models include a number of controls previously identified as important determinants of anti-immigrant attitudes. Since individuals who struggle economically are generally more vulnerable to economic competition from new arrivals, we include indicators of people's income, employment status, and professional skills. In addition, our models account for respondents' ideological beliefs, as right-wing orientations are generally linked to stronger support for traditional values and practices, perceptions of immigration as a symbolic threat to a nation, and therefore more skeptical views about new arrivals (e.g., Betz and Immerfall 1998; Bilodeau and Fadol 2011; McLaren 2003; Wilkes, Guppy, and Farris 2008).

Several survey items are used to capture immigrants' experiences in receiving countries. Since newcomers' attitudes may be affected by their exposure to, and their personal or group situation in, a receiving country, we control for how recently a foreigner arrived to his or her host country, whether one belongs to a minority ethnic group, and has been discriminated against. In addition, to capture the possible consequences of special rights and privileges enjoyed by EU citizens in comparison to third-country nationals, our models take into account whether a foreigner was born in an EU member state. Finally, we include measures of so-

9. Foreign-born respondents with both native-born parents were excluded from the analyses.

10. We rely on subjective economic evaluations instead of official indicators of the functioning of the economy because subjective indicators provide more direct measures of what we seek to measure (people's perceptions of the economy) and are causally closer to our dependent variables (people's attitudes towards immigration) than objective indicators, such as official estimates of GDP per capita, inflation, or unemployment. cial connectedness and urban residence along with standard demographic variables-education, age, and gender-that have been found to influence immigration attitudes in previous research (e.g., Bilodeau and Fadol 2011; Chandler and Tsai 2001; Hainmueller and Hiscox 2007; McLaren 2003; Quillian 1995) (details on variable coding are listed in the online appendix).

\section{ANALYSIS AND RESULTS}

A first look at the data reveals that, on average, foreigners have more favorable attitudes towards immigration than native-born respondents: the mean values are 6.26 for foreign-born survey respondents and 5.07 for natives on the 0 to 10 scale measuring how favorably people evaluate the consequences of immigration, and 6.09 vs. 5.15, respectively, on the scale capturing beliefs about the appropriate levels of immigration. Furthermore, the results show that foreignborn citizens express less favorable views toward immigration than foreign-born noncitizens: the respective mean values are 5.92 and 6.55 for perceived consequences of immigration, and 5.87 vs. 6.28 for preferred levels of immigration. The results of multivariate estimations (not reported here but available upon request) also show that native-born status and citizenship have negative and statistically significant effects on people's attitudes towards new arrivals. These results provide initial support for our hypothesis that foreigners express more support for immigration than natives and for the notion that foreigners who have acquired citizenship fall somewhere between native-born citizens and foreignborn noncitizens.

To examine the determinants of immigration attitudes among foreigners in greater detail, we turn exclusively to foreign-born respondents. Since we combine information collected at the level of individuals and at the level of countries, our dataset has a multilevel structure. To avoid a number of statistical problems associated with such a data structure (clustering, nonconstant variance, incorrect standard errors, etc.) (cf. Snijders and Bosker 1999; Steenbergen and Jones 2002), we rely on multilevel mixed-effects models, that is, models with random intercepts (to allow for crosscountry heterogeneity in levels of immigration support) and random slopes for our citizenship variable (to allow for cross-country variability in the magnitude of citizenship coefficients). ${ }^{11}$

The results presented in Table 1 (first column for each dependent variable) reveal that citizenship is indeed negatively

11. The results of a variance-components model (ANOVA) (available from the authors upon request) show statistically significant variability in immigration attitudes at both levels of analysis. 
linked to immigration support among foreign-born respondents and that this relationship is highly statistically significant with respect to both dependent variables. Specifically, foreigners who have acquired citizenship in their host country report more skeptical views about the consequences of immigration and express less support for allowing more migrants to come to their adopted homelands than foreigners without citizenship. Hence, as hypothesized, granting immigrants formal membership in the political community of their receiving countries is associated with lower levels of support for immigration.

Other variables exhibit some noteworthy patterns as well. Dissatisfaction with the state of macroeconomy has a consistent and negative effect on immigration support, and this effect is statistically significant in the models of both perceived consequences of immigration and beliefs about the appropriate levels of immigration. Interestingly, personal income plays no detectable role in shaping foreigners' attitudes about immigration, although individuals with manual skills express more skeptical views about immigration than highly skilled professionals. At the same time, ideological beliefs matter too, as our results demonstrate a consistent negative relationship between right-wing orientations and immigration support. However, opposition to new arrivals weakens with social connectedness and education - the two variables known to generate more tolerant and multicultural views (Chandler and Tsai 2001; Hainmueller and Hiscox 2007).

Among the sociodemographic variables, age is linked to lower support for immigration, although our data does not allow us to assess to what extent this relationship is due to generational as opposed to life-cycle effects. Moreover, urban residents and men express more positive opinions about the consequences of immigration, but these variables have no statistically significant effects on attitudes with respect to the appropriate levels of immigration. Moreover, while discrimination experiences encourage foreigners to be more sympathetic to the issue of immigration and new arrivals, immigrant-specific variables do not have consistent effects. Specifically, foreigners who arrived more recently view immigration consequences for their host country in a more positive light than earlier arrivals, but they are not significantly different from each other in their attitudes towards allowing more immigrants to come in. In contrast, being a foreigner from an EU country (as opposed to being a third-country national) is linked to more positive immigrant admission attitudes but has no detectable relationship with evaluations of immigration consequences on one's adopted homeland. Taken together, our results reveal that, while attitudes towards immigration among foreign-born in Eu- rope are linked to many traditional predictors of natives' support for immigration, they are also consistently shaped by immigrants' formal incorporation into the host society via citizenship.

\section{MULTILEVEL RESULTS WITH COARSENED EXACT MATCHING (CEM)}

One shortcoming of observational data is that, compared to randomized experiments, the data-generation process-including the treatment assignment mechanism (in our case citizenship acquisition among foreign-born individuals) — is not controlled by the investigator and therefore is unknown or ambiguous. The traditional ways of handling endogeneity among dependent and independent variables include structural equation or instrumental variable approaches to exogenize the independent variable of interest. Another, more straightforward way to improve causal inferences using observational data is to rely on data preprocessing techniques known as matching-a nonparametric approach designed to control for the confounding influence of pretreatment variables and consequently reduce model dependence and statistical bias (Ho et al. 2007). ${ }^{12}$ A reduction in model dependence achieved via preprocessing data through matching also means that specific modeling choices on the part of the investigator influence the estimate of the causal quantity of interest considerably less than would be the case without matching. Matching achieves this by pruning observations from the data so that the remaining observations are left with a better balance in the empirical distributions of the covariates between the treated and control groups.

The "coarsened exact matching" (CEM) method, recently developed by Gary King and his colleagues, has been shown to be a very useful technique due to its multiple statistical properties such as the ability to reduce imbalance, model dependence, statistical bias, estimation error, and variance. It also is highly computationally efficient and easy to use in a variety of statistical programs (Blackwell et al. 2009; Iacus, King, and Porro 2012, 2011). The central motivation for CEM is that, while exact matching provides perfect balance by pairing a treated unit to all the control units with the same covariate values, it typically produces too few matches because of the curse-of-dimensionality issue. For example, introducing one continuous variable into a model effectively precludes exact matching because any two observations are unlikely to have identical values on a continuous measure. CEM provides a solution to this problem by temporarily coarsening the values of the covariates into substantively meaningful categories, exact matching of observations on these

12. For an overview of matching methods, see Stuart (2010). 
Table 1. Pro-Immigration Attitudes among Foreign-Born Individuals in 18 European Countries, 2002-11

\begin{tabular}{|c|c|c|c|c|}
\hline \multirow[b]{2}{*}{ Independent Variables } & \multicolumn{2}{|c|}{ Perceived Consequences of Immigration } & \multicolumn{2}{|c|}{ Preferred Immigration Levels } \\
\hline & Multilevel & $\begin{array}{l}\text { Multilevel } \\
\text { CEM k2k }\end{array}$ & Multilevel & $\begin{array}{l}\text { Multilevel } \\
\text { CEM k2k }\end{array}$ \\
\hline Citizen & $\begin{array}{c}-.328^{\star} \\
(.086)\end{array}$ & $\begin{array}{c}-.288^{*} \\
(.093)\end{array}$ & $\begin{array}{r}-.328^{*} \\
(.067)\end{array}$ & $\begin{array}{r}-.280^{*} \\
(.132)\end{array}$ \\
\hline Dissatisfaction with economy & $\begin{array}{c}-.133^{\star} \\
(.008)\end{array}$ & $\begin{array}{c}-.132^{\star} \\
(.021)\end{array}$ & $\begin{array}{r}-.074^{\star} \\
(.011)\end{array}$ & $\begin{array}{r}-.076^{\star} \\
(.028)\end{array}$ \\
\hline Manual skills & $\begin{array}{c}-.211^{\star} \\
(.039)\end{array}$ & $\begin{array}{c}-.357^{\star} \\
(.111)\end{array}$ & $\begin{array}{r}-.298^{\star} \\
(.050)\end{array}$ & $\begin{array}{r}-.388^{*} \\
(.144)\end{array}$ \\
\hline Income & $\begin{array}{c}.013 \\
(.023)\end{array}$ & $\begin{array}{c}.063 \\
(.072)\end{array}$ & $\begin{array}{c}.047 \\
(.030)\end{array}$ & $\begin{array}{c}.244^{*} \\
(.093)\end{array}$ \\
\hline Unemployed & $\begin{array}{r}-.143^{\star} \\
(.065)\end{array}$ & $\begin{array}{r}-.019 \\
(.364)\end{array}$ & $\begin{array}{c}.018 \\
(.083)\end{array}$ & $\begin{array}{r}-.309 \\
(.468)\end{array}$ \\
\hline Left-right self-placement & $\begin{array}{c}-.103^{\star} \\
(.009)\end{array}$ & $\begin{array}{c}-.127^{\star} \\
(.023)\end{array}$ & $\begin{array}{r}-.139^{*} \\
(.011)\end{array}$ & $\begin{array}{r}-.182^{\star} \\
(.030)\end{array}$ \\
\hline Recent immigrant & $\begin{array}{c}.052^{\star} \\
(.020)\end{array}$ & $\begin{array}{c}.094 \\
(.055)\end{array}$ & $\begin{array}{c}.029 \\
(.026)\end{array}$ & $\begin{array}{c}.103 \\
(.072)\end{array}$ \\
\hline Ethnic minority & $\begin{array}{c}.271^{\star} \\
(.045)\end{array}$ & $\begin{array}{c}.453^{*} \\
(.146)\end{array}$ & $\begin{array}{l}.118^{\star} \\
(.057)\end{array}$ & $\begin{array}{c}.068 \\
(.190)\end{array}$ \\
\hline Discriminated against & $\begin{array}{c}.265^{\star} \\
(.053)\end{array}$ & $\begin{array}{c}.129 \\
(.240)\end{array}$ & $\begin{array}{l}.316^{*} \\
(.067)\end{array}$ & $\begin{array}{l}.675^{*} \\
(.311)\end{array}$ \\
\hline Social connectedness & $\begin{array}{c}.087^{\star} \\
(.012)\end{array}$ & $\begin{array}{c}.100^{*} \\
(.031)\end{array}$ & $\begin{array}{l}.070^{\star} \\
(.015)\end{array}$ & $\begin{array}{c}.068 \\
(.040)\end{array}$ \\
\hline Urban residence & $\begin{array}{c}.081^{\star} \\
(.016)\end{array}$ & $\begin{array}{c}.078 \\
(.040)\end{array}$ & $\begin{array}{c}.024 \\
(.020)\end{array}$ & $\begin{array}{r}-.011 \\
(.052)\end{array}$ \\
\hline Education & $\begin{array}{c}.052^{\star} \\
(.004)\end{array}$ & $\begin{array}{c}.053^{*} \\
(.012)\end{array}$ & $\begin{array}{l}.056^{*} \\
(.006)\end{array}$ & $\begin{array}{c}.054^{\star} \\
(.016)\end{array}$ \\
\hline Age & $\begin{array}{r}-.006^{*} \\
(.001)\end{array}$ & $\begin{array}{c}-.001 \\
(.004)\end{array}$ & $\begin{array}{r}-.014^{*} \\
(.002)\end{array}$ & $\begin{array}{r}-.007 \\
(.005)\end{array}$ \\
\hline Male & $\begin{array}{c}.149^{*} \\
(.036)\end{array}$ & $\begin{array}{c}.124 \\
(.092)\end{array}$ & $\begin{array}{c}.057 \\
(.046)\end{array}$ & $\begin{array}{c}.086 \\
(.119)\end{array}$ \\
\hline Foreign-born from the $\mathrm{EU}$ & $\begin{array}{c}-.025 \\
(.042)\end{array}$ & $\begin{array}{c}.030 \\
(.112)\end{array}$ & $\begin{array}{l}.123^{*} \\
(.054)\end{array}$ & $\begin{array}{l}.164 \\
(.147)\end{array}$ \\
\hline ESS1 & $\begin{array}{c}.228^{*} \\
(.058)\end{array}$ & $\begin{array}{c}.083 \\
(.144)\end{array}$ & $\begin{array}{l}.200^{*} \\
(.075)\end{array}$ & $\begin{array}{r}-.163 \\
(.189)\end{array}$ \\
\hline ESS2 & $\begin{array}{c}.005 \\
(.058)\end{array}$ & $\begin{array}{c}-.032 \\
(.146)\end{array}$ & $\begin{array}{l}.278^{\star} \\
(.074)\end{array}$ & $\begin{array}{r}-.226 \\
(.190)\end{array}$ \\
\hline ESS3 & $\begin{array}{c}-.034 \\
(.057)\end{array}$ & $\begin{array}{c}.101 \\
(.154)\end{array}$ & $\begin{array}{c}.036 \\
(.073)\end{array}$ & $\begin{array}{r}-.243 \\
(.200)\end{array}$ \\
\hline ESS4 & $\begin{array}{c}.195^{\star} \\
(.055)\end{array}$ & $\begin{array}{c}.280^{*} \\
(.139)\end{array}$ & $\begin{array}{c}.288^{\star} \\
(.070)\end{array}$ & $\begin{array}{c}.101 \\
(.179)\end{array}$ \\
\hline Constant & $\begin{array}{l}6.209^{*} \\
(.195)\end{array}$ & $\begin{array}{l}5.882^{*} \\
(.470)\end{array}$ & $\begin{array}{l}6.363^{\star} \\
(.258)\end{array}$ & $\begin{array}{l}6.013^{*} \\
(.621)\end{array}$ \\
\hline Variance of random slope: citizen & $\begin{array}{c}.088 \\
(.041)\end{array}$ & $\begin{array}{c}.000 \\
(.000)\end{array}$ & $\begin{array}{c}.022 \\
(.018)\end{array}$ & $\begin{array}{c}.034 \\
(.080)\end{array}$ \\
\hline
\end{tabular}




\begin{tabular}{|c|c|c|c|c|}
\hline \multirow[b]{2}{*}{ Independent Variables } & \multicolumn{2}{|c|}{ Perceived Consequences of Immigration } & \multicolumn{2}{|c|}{ Preferred Immigration Levels } \\
\hline & Multilevel & $\begin{array}{l}\text { Multilevel } \\
\text { CEM k2k }\end{array}$ & Multilevel & $\begin{array}{l}\text { Multilevel } \\
\text { CEM k2k }\end{array}$ \\
\hline Variance of random intercept & $\begin{array}{c}.148 \\
(.056)\end{array}$ & $\begin{array}{c}.100 \\
(.048)\end{array}$ & $\begin{array}{c}.332 \\
(.125)\end{array}$ & $\begin{array}{c}.390 \\
(.178)\end{array}$ \\
\hline Variance of residuals & $\begin{array}{l}2.979 \\
(.043)\end{array}$ & $\begin{array}{l}2.737 \\
(.104)\end{array}$ & $\begin{array}{l}4.762 \\
(.070)\end{array}$ & $\begin{array}{l}4.489 \\
(.174)\end{array}$ \\
\hline Number of observations & 9,518 & 1,391 & 9,356 & 1,363 \\
\hline Wald $X^{2}$ (df) & $1,150.21(19)^{\star}$ & $232.7(19)^{\star}$ & $976.64(19)^{\star}$ & $145.69(19)^{*}$ \\
\hline
\end{tabular}

Note-Results are multilevel mixed effects (random slope and random intercept) linear regression estimates (using STATA's xtmixed command). ESS5 is a reference category for survey rounds. Numbers in parentheses represent standard errors;

${ }^{*} p<.05$ (two-tailed).

coarsened values, and then employing original (uncoarsened) covariates and statistical estimations they would ordinarily use on the matched data.

To test the robustness of our findings, that is, to see whether citizenship is indeed linked to lower support for immigration as we posit, we take advantage of this statistical technique to preprocess our data and then reestimate our multilevel models with the matched observations. ${ }^{13} \mathrm{We}$ rely on the $\mathrm{k} 2 \mathrm{k}$ matching solution that produces equal number of treated and control units within strata, eliminating the need for weights in subsequent estimations. ${ }^{14}$ Since our main analyses employ multilevel modeling where implementing weights may require rescaling them for each level of analysis (e.g., Carle 2009), we chose the k2k option allowing us to proceed without weights. ${ }^{15}$

We used all our covariates (except citizenship) in the matching procedure. Since many of our variables include multiple categories in their original coding, to maintain a sufficiently large number of matched cases for efficient estimations and coarsen our covariates into substantively meaningful categories, we proceeded in the following way: dissatisfaction with economy, recent immigrant, education, social connectedness, urban residence were coarsened into two category variables using median values among foreign-

13. All analyses were conducted in Stata; for guidelines how to implement CEM in Stata, see Blackwell et al. (2009).

14. Such weights are required after the default CEM algorithm that generates strata containing varied numbers of treated and control units, and weights are applied to correct for these differences.

15. However, as we note below, the default CEM algorithm using weights produces nearly identical results (available from the authors upon request). born respondents (the median for education corresponds to the substantively meaningful value of 12 years of full-time education completed, or having a high school diploma). Left-right self-placement was recoded into a three-category variable by grouping those on the left (values $0-4$ in the original variable coding), center (5), and right (6-10), while age was similarly coarsened using 30 -year intervals, that is, respondents who are 29 years old or younger, 30-59, and 60 or older). Dichotomous covariates (unemployment, male, manual skills, ethnic minority, discriminated against, foreignborn from the EU, and ESS rounds) were left unchanged (see the online appendix for full information on variable coding). Applying the CEM algorithm on data coarsened in this way results in perfect global balance, as the $\mathfrak{E}_{1}$ statistic for the full joint distribution of the covariates declines from .856 for the unmatched observations to zero for the matched ones, while each individual covariate becomes perfectly balanced as well. ${ }^{16}$

The results of multilevel estimations on the matched data (reported in Table 1, second column for each dependent variable) reveal that our findings remain essentially the same: we still observe that citizenship is associated with lower levels of immigration support. Although the coefficient for this variable is slightly weaker in substantive and statistical terms, it remains consistently negative and statistically significant in the models for both dependent vari-

16. This matching procedure generates 749 matched strata, containing 788 matched treatment units and the same number of matched control units. The number of cases drops from 9,518 to 1,391 in the models of perceived consequences of immigration and from 9,356 to 1,363 in the models of preferred immigration levels. 
Table 2. Interaction Models of Pro-Immigration Attitudes among Foreign-Born Individuals in 18 European Countries, 2002-11

\begin{tabular}{|c|c|c|c|c|}
\hline \multirow[b]{2}{*}{ Independent Variables } & \multicolumn{2}{|c|}{ Perceived Consequences of Immigration } & \multicolumn{2}{|c|}{ Preferred Immigration Levels } \\
\hline & Multilevel & $\begin{array}{l}\text { Multilevel } \\
\text { CEM k2k }\end{array}$ & Multilevel & $\begin{array}{l}\text { Multilevel } \\
\text { CEM k2k }\end{array}$ \\
\hline Citizen & $\begin{array}{c}-.265^{\star} \\
(.112)\end{array}$ & $\begin{array}{r}-.135 \\
(.188)\end{array}$ & $\begin{array}{r}-.086 \\
(.111)\end{array}$ & $\begin{array}{c}.235 \\
(.248)\end{array}$ \\
\hline Dissatisfaction with economy & $\begin{array}{c}-.126^{\star} \\
(.011)\end{array}$ & $\begin{array}{c}-.114^{\star} \\
(.029)\end{array}$ & $\begin{array}{c}-.049^{\star} \\
(.014)\end{array}$ & $\begin{array}{r}-.018 \\
(.037)\end{array}$ \\
\hline Citizen ${ }^{*}$ Dissatisfaction with economy & $\begin{array}{c}-.013 \\
(.015)\end{array}$ & $\begin{array}{c}-.035 \\
(.037)\end{array}$ & $\begin{array}{c}-.050^{*} \\
(.019)\end{array}$ & $\begin{array}{c}-.113^{\star} \\
(.049)\end{array}$ \\
\hline Manual skills & $\begin{array}{c}-.210^{\star} \\
(.039)\end{array}$ & $\begin{array}{c}-.358^{\star} \\
(.111)\end{array}$ & $\begin{array}{c}-.298^{\star} \\
(.050)\end{array}$ & $\begin{array}{c}-.393^{\star} \\
(.144)\end{array}$ \\
\hline Income & $\begin{array}{c}.013 \\
(.023)\end{array}$ & $\begin{array}{c}.062 \\
(.072)\end{array}$ & $\begin{array}{c}.046 \\
(.030)\end{array}$ & $\begin{array}{c}.242^{*} \\
(.093)\end{array}$ \\
\hline Unemployed & $\begin{array}{c}-.144^{\star} \\
(.065)\end{array}$ & $\begin{array}{c}-.028 \\
(.364)\end{array}$ & $\begin{array}{c}.015 \\
(.083)\end{array}$ & $\begin{array}{r}-.333 \\
(.467)\end{array}$ \\
\hline Left-right self-placement & $\begin{array}{c}-.103^{\star} \\
(.009)\end{array}$ & $\begin{array}{c}.127^{\star} \\
(.023)\end{array}$ & $\begin{array}{c}-.139^{*} \\
(.011)\end{array}$ & $\begin{array}{c}-.180^{*} \\
(.030)\end{array}$ \\
\hline Recent immigrant & $\begin{array}{c}.053^{\star} \\
(.020)\end{array}$ & $\begin{array}{c}.093 \\
(.055)\end{array}$ & $\begin{array}{c}.033 \\
(.026)\end{array}$ & $\begin{array}{c}.102 \\
(.072)\end{array}$ \\
\hline Ethnic minority & $\begin{array}{c}.271^{\star} \\
(.045)\end{array}$ & $\begin{array}{c}.448^{*} \\
(.146)\end{array}$ & $\begin{array}{c}.116^{*} \\
(.057)\end{array}$ & $\begin{array}{c}.048 \\
(.189)\end{array}$ \\
\hline Discriminated against & $\begin{array}{c}.265^{\star} \\
(.053)\end{array}$ & $\begin{array}{c}.131 \\
(.240)\end{array}$ & $\begin{array}{c}.312^{*} \\
(.067)\end{array}$ & $\begin{array}{c}.685^{*} \\
(.311)\end{array}$ \\
\hline Social connectedness & $\begin{array}{c}.087^{\star} \\
(.012)\end{array}$ & $\begin{array}{c}.100^{\star} \\
(.031)\end{array}$ & $\begin{array}{c}.071^{\star} \\
(.015)\end{array}$ & $\begin{array}{c}.067 \\
(.040)\end{array}$ \\
\hline Urban residence & $\begin{array}{c}.081^{\star} \\
(.016)\end{array}$ & $\begin{array}{c}.077 \\
(.040)\end{array}$ & $\begin{array}{c}.024 \\
(.020)\end{array}$ & $\begin{array}{r}-.013 \\
(.052)\end{array}$ \\
\hline Education & $\begin{array}{c}.052^{\star} \\
(.004)\end{array}$ & $\begin{array}{c}.053^{*} \\
(.012)\end{array}$ & $\begin{array}{c}.056^{\star} \\
(.006)\end{array}$ & $\begin{array}{c}.053^{*} \\
(.016)\end{array}$ \\
\hline Age & $\begin{array}{c}-.006^{*} \\
(.001)\end{array}$ & $\begin{array}{c}-.001 \\
(.004)\end{array}$ & $\begin{array}{c}-.014^{\star} \\
(.002)\end{array}$ & $\begin{array}{c}-.007 \\
(.005)\end{array}$ \\
\hline Male & $\begin{array}{c}.148^{\star} \\
(.036)\end{array}$ & $\begin{array}{c}.124 \\
(.091)\end{array}$ & $\begin{array}{c}.055 \\
(.046)\end{array}$ & $\begin{array}{c}.082 \\
(.119)\end{array}$ \\
\hline Foreign-born from the EU & $\begin{array}{c}-.024 \\
(.042)\end{array}$ & $\begin{array}{c}.029 \\
(.112)\end{array}$ & $\begin{array}{c}.123^{*} \\
(.054)\end{array}$ & $\begin{array}{c}.159 \\
(.146)\end{array}$ \\
\hline ESS1 & $\begin{array}{c}.229^{*} \\
(.058)\end{array}$ & $\begin{array}{c}.083 \\
(.144)\end{array}$ & $\begin{array}{c}.206^{*} \\
(.075)\end{array}$ & $\begin{array}{c}-.160 \\
(.189)\end{array}$ \\
\hline ESS2 & $\begin{array}{c}.007 \\
(.058)\end{array}$ & $\begin{array}{c}-.031 \\
(.146)\end{array}$ & $\begin{array}{c}.282^{\star} \\
(.074)\end{array}$ & $\begin{array}{r}-.225 \\
(.190)\end{array}$ \\
\hline ESS3 & $\begin{array}{c}-.033 \\
(.057)\end{array}$ & $\begin{array}{c}.101 \\
(.154)\end{array}$ & $\begin{array}{c}.042 \\
(.073)\end{array}$ & $\begin{array}{c}-.240 \\
(.199)\end{array}$ \\
\hline ESS4 & $\begin{array}{c}.197^{\star} \\
(.055)\end{array}$ & $\begin{array}{c}.280^{*} \\
(.139)\end{array}$ & $\begin{array}{c}.293^{*} \\
(.070)\end{array}$ & $\begin{array}{c}.104 \\
(.179)\end{array}$ \\
\hline Constant & $\begin{array}{l}6.175^{\star} \\
(.199)\end{array}$ & $\begin{array}{l}5.815^{\star} \\
(.476)\end{array}$ & $\begin{array}{l}6.231^{*} \\
(.263)\end{array}$ & $\begin{array}{l}5.786^{*} \\
(.627)\end{array}$ \\
\hline
\end{tabular}




\begin{tabular}{|c|c|c|c|c|}
\hline \multirow[b]{2}{*}{ Independent Variables } & \multicolumn{2}{|c|}{ Perceived Consequences of Immigration } & \multicolumn{2}{|c|}{ Preferred Immigration Levels } \\
\hline & Multilevel & $\begin{array}{l}\text { Multilevel } \\
\text { CEM k2k }\end{array}$ & Multilevel & $\begin{array}{l}\text { Multilevel } \\
\text { CEM k2k }\end{array}$ \\
\hline Variance of random slope: citizen & $\begin{array}{c}.083 \\
(.040)\end{array}$ & $\begin{array}{c}.000 \\
(.000)\end{array}$ & $\begin{array}{c}.017 \\
(.017)\end{array}$ & $\begin{array}{c}.013 \\
(.072)\end{array}$ \\
\hline Variance of random intercept & $\begin{array}{c}.148 \\
(.056)\end{array}$ & $\begin{array}{c}.100 \\
(.048)\end{array}$ & $\begin{array}{c}.334 \\
(.126)\end{array}$ & $\begin{array}{c}.394 \\
(.179)\end{array}$ \\
\hline Variance of residuals & $\begin{array}{l}2.978 \\
(.043)\end{array}$ & $\begin{array}{l}2.735 \\
(.104)\end{array}$ & $\begin{array}{l}4.759 \\
(.070)\end{array}$ & $\begin{array}{l}4.475 \\
(.173)\end{array}$ \\
\hline Number of observations & 9,518 & 1,391 & 9,356 & 1,363 \\
\hline Wald $X^{2}(\mathrm{df})$ & $1,153.02(20)^{*}$ & $233.73(20)^{\star}$ & $810.50(20)^{\star}$ & $151.71(20)^{\star}$ \\
\hline
\end{tabular}

Note-Results are multilevel mixed effects (random slope and random intercept) linear regression estimates (using STATA's xtmixed command). ESS5 is a reference category for survey rounds. Numbers in parentheses represent standard errors; ${ }^{*} p<.05$ (two-tailed).

ables. Moreover, the results remain the same when, instead of using a $2 \mathrm{k}$ match, we preprocess our data with the default CEM algorithm and then apply CEM weights in subsequent estimations (available from the authors upon request). ${ }^{17}$ In short, these additional analyses confirm that citizenship plays an important role in shaping immigrants' views about immigrations and that these findings are robust to the use of different statistical techniques.

\section{CONTINGENT EFFECTS OF CITIZENSHIP}

In addition to assessing the direct effects of citizenship, we were also interested in the extent to which citizenship status interacts with economic evaluations in shaping immigration support among foreign-born individuals. The results of our interaction models, reported in Table 2, reveal that the impact of citizenship should not be considered in isolation. Specifically, we find that the multiplicative term between citizenship and dissatisfaction with the economy is negative and statistically significant in the model of preferred immigration levels. This means that, while dissatisfaction with the economy generally erodes immigrants' support for continued immigration, this effect becomes amplified among foreignborn individuals who have acquired citizenship in their host country. To put it differently, foreigners formally incorporated into the political community of their adopted homeland are more inclined to connect their economic eval-

17. CEM weights in mixed effects models using Stata were applied using "pweight" along with the "pwscale" option designed to control the scaling of weights in multilevel analyses. uations to assessments whether their host country should allow more migrants to come in. Interestingly, the additive term of citizenship is not statistically significant once we include the interaction between citizenship and economic evaluations, indicating that among foreigners fully satisfied with macroeconomy, citizenship plays no role in shaping their support for immigration.

To assess how much citizenship and dissatisfaction with economy matter in substantive terms, we calculated marginal effects using the CEM preprocessed multilevel results from the interaction model for preferred levels of immigration among foreign-born (reported in the last column of Table 2). Following recent suggestions for testing conditional hypotheses (Berry, Golder, and Milton 2012), we plot these effects (with 95\% confidence intervals) using two figures: Figure 1 that shows the marginal effect of citizenship at various levels of dissatisfaction with the economy, and Figure 2 demonstrating the marginal effect of dissatisfaction with the economy for citizens and noncitizens.

The results reveal that our key variables of interest indeed have a sizable effect on foreigners' beliefs about the appropriate levels of immigration to their host country. Specifically, Figure 1 shows that the marginal effect of citizenship changes from .235 to -.899 , as we move from the lowest to the highest value of dissatisfaction with economy, and becomes statistically distinguishable from 0 at the value of 4.5 (on a scale from 0 to 10 ) of the dissatisfaction with economy variable. This means that citizenship undermines pro-immigrant views even among foreigners who are neither satisfied nor dissatisfied with the functioning of macro- 


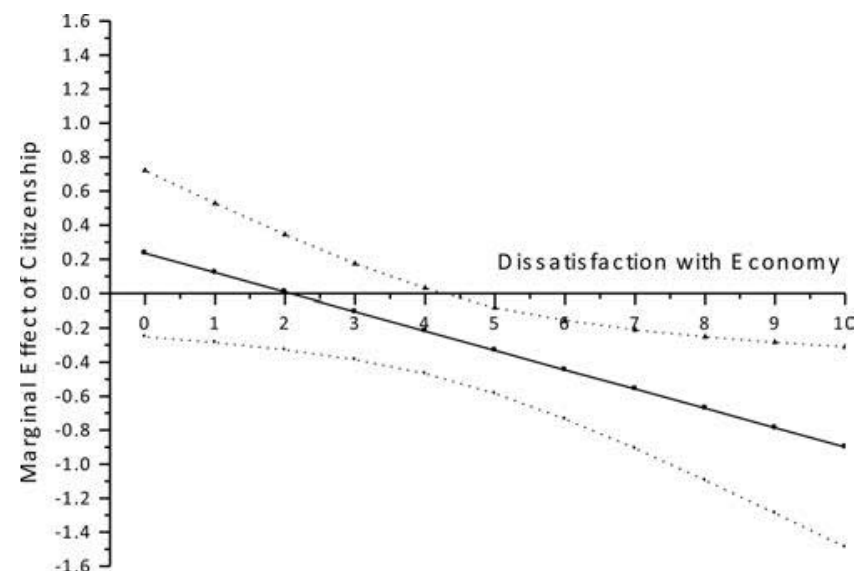

Figure 1. Marginal effect of citizenship on preferred levels of immigration among foreign-born individuals in 18 western democracies. Dashed lines indicate $95 \%$ confidence intervals.

economy, and this effect becomes increasingly pronounced at higher levels of dissatisfaction.

Figure 2 provides additional support for our conditional hypothesis. Specifically, it demonstrates that, while the marginal effect of dissatisfaction with the economy is equal to -.018 among foreign-born noncitizens, its magnitude rises to -.132 among foreigners who have acquired citizenship. This effect, however, is statistically distinguishable from 0 only among foreign-born citizens. In short, calculations of the marginal effects confirm our expectations that citizenship and dissatisfaction with economy amplify each other's negative effect and that both variables play a sizable role in undermining support for continued immigration among foreign-born individuals.

\section{DISCUSSION}

International migration has become a persistent feature of contemporary societies. People move across borders looking for a better life, more fulfilling jobs, greater opportunities for acquiring new skills and ideas, or simply a more pleasant retirement. They also migrate to escape war, political persecution, or natural disasters. For better or for worse, migration has been on the rise in recent decades and is unlikely to subside in an increasingly interdependent world marked by economic and political differences, extended civil wars, as well as changing and less predictable climatic patterns. Moreover, some argue that migration will continue in the future because it is intimately intertwined with the processes of economic development (de Haas 2007), sustained by migrant social networks (Money 1999, 9; Munck 2008), and shielded from public hostility by legal commitments of liberal democracies to protect individual and family unification rights (Freeman 1995; Joppke 1998).
While migration affects both immigrant-sending and receiving countries, as well as migrants themselves, previous cross-national research on immigration attitudes has focused exclusively on native-born populations. In contrast, little is known about the views of individuals who have personal experiences with migration and are directly affected by migration and immigrant incorporation policies in their host societies. In particular, we still lack a general understanding based on systematic cross-national research how immigrant political views and behavior are shaped by experiences unique to immigrants and the extent to which the effects of these experiences complement, replace, or interact with the consequences of other individual or contextual characteristics.

Our study sought to contribute to this area of research by focusing on what foreigners think about other immigrants and immigration and what explains these attitudes. Specifically, we asked whether foreigners perceive immigration more favorably than natives, whether these attitudes are affected by similar considerations as among natives, and whether the formal incorporation of immigrants into their host societies interacts with these considerations in shaping their immigration views. Insights into these questions should enable policy makers to better predict and prevent more violent expressions of disaffection among new arrivals, adopt more adequate immigrant admission and incorporation policies, and facilitate the development of more tolerant and cohesive communities in contemporary democracies with large immigrant populations.

We argue that the attitudes towards immigration among foreign-born residents are marked by competing motivations. On one hand, migrants express more positive views about immigration than natives. We posit, although cannot

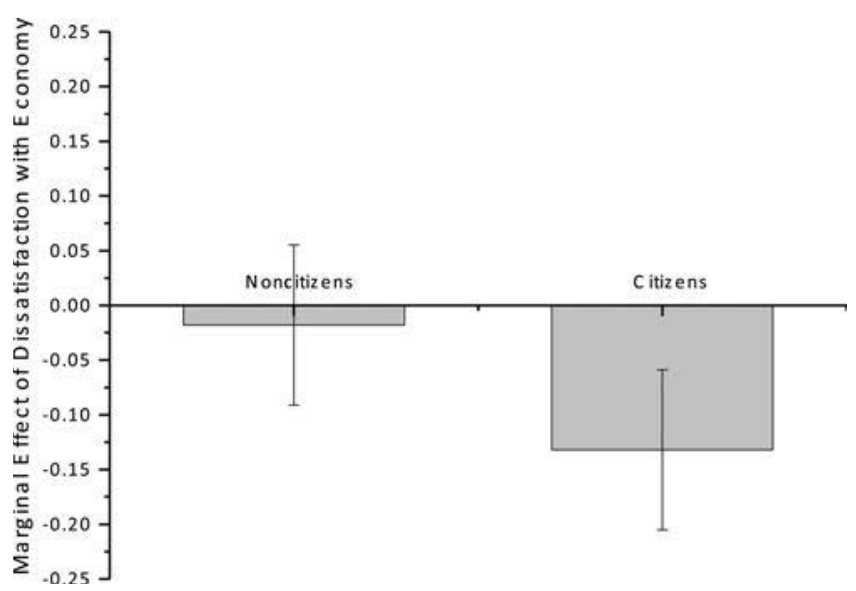

Figure 2. Marginal effect of dissatisfaction with economy on preferred levels of immigration among foreign-born individuals in 18 western democracies. Vertical lines indicate $95 \%$ confidence intervals. 
test directly, that this effect is rooted in a variety of considerations; these include kinship and solidarity with other newcomers based on their shared experiences as migrants; a better understanding why people migrate and the physical and psychological difficulties that relocation to a different country involves; instrumental considerations, such as opportunities to bring in their relatives from abroad; as well as cognitive dissonance avoidance that encourages individuals who made the choice to migrate themselves to evaluate that same choice made by others positively. On the other hand, the formal incorporation via citizenship and negative evaluations of the macroeconomy motivate foreigners to be more cautious in expressing support for immigration and lead to a convergence between the attitudes of natives and foreigners who have become better integrated into their host societies.

Our analyses of individual-level survey data from 18 West European democracies using coarsened exact matching and multilevel estimations reveal that individuals born abroad have significantly more sanguine attitudes towards immigration than natives. This suggests that foreigners may have a shared interest to promote more liberal immigration policies and could be useful allies to business groups lobbying for more flexible labor markets or human rights organizations in favor of more open borders for humanitarian purposes (admitting refugees, asylum seekers, etc.). At the same time, we find considerable variation in immigrants' attitudes towards immigration: some of it is due to the same factors as support for immigration among natives in established democracies. Specifically, worries about the macroeconomy, a lack of professional skills and education, as well as rightwing ideological views are responsible for more skeptical assessments of immigration, while unemployment status or income have limited effect. Most importantly, formal incorporation into the political community of one's host country via the route of citizenship is consistently and powerfully linked to more negative views about immigration among foreign-born individuals. Our analyses also show that dissatisfaction with macroeconomy amplifies the negative relationship between citizenship and immigration support, but only with respect to preferred levels of immigration, as we find no evidence of this interaction effect in evaluating immigration consequences more generally.

Taken together, our results suggest that, just like natives, foreigners, particularly when they enjoy citizenship status in their host country, assess immigration largely in light of socio-tropic economic considerations about their host society. These findings paint an image of foreigners committed to their adopted country rather than a group of highly individualistic and self-serving residents. Thus, in contrast to fears of immigration skeptics who believe that granting foreigners citizenship rights may create new political tensions and lead to the loss of control enjoyed by the native populations, our results indicate that the formal incorporation of foreigners into the body politic of their host country is associated with convergent views among foreigners and natives and that naturalization helps to motivate immigrants to place greater emphasis on collective (national) concerns in forming their opinions about immigration.

While this study examined foreign-born individuals, future research would benefit also from understanding how immigrants' attitudes towards immigration vary across immigrant generations. Existing literature from the United States indicates that foreign-born individuals are generally more positive about immigration and policies that benefit newcomers than second- or third-generation immigrants (e.g., Binder, Polinard, and Wrinkle 1997; Branton 2007; Miller, Polinard, and Wrinkle 1984; Polinard, Miller, and de la Garza 1984).$^{18}$ A similar pattern may be expected in Europe as well, although a sense of exclusion among some sizable groups of new arrivals, such as Muslim immigrants, and the fact that not all second-generation immigrants receive citizenship by virtue of being born on the soil of their host countries, may result in considerably smaller differences between first- and second-generation immigrants in their support for immigration in this part of the world than in the United States or other traditional immigration countries. Systematic analyses of how anti-immigrant sentiment varies across immigrant generations along with citizenship status, religion, ethnicity, as well as other markers of identity may add interesting insights to understanding newcomers' political attitudes and policy preferences in contemporary democracies.

We conclude that, while the migration experience encourages foreigners to evaluate immigration more positively than do natives, host societies are not completely powerless when it comes to shaping attitudes among immigrants in their countries. Our study suggests that, by facilitating the formal immigrant incorporation into the body politic via the route of citizenship, governments can encourage foreigners to behave as more responsible members of their societies and pay more attention to national concerns in shaping their attitudes towards issues that are likely to play an important role in the policymaking of many democracies in the foreseeable future.

18. For a more general discussion of differences between immigrants of different generations in the United States, see, for example, Portes and Rubmaut $(2001,2006)$ and Portes and Zhou (1993). 


\section{REFERENCES}

Barreto, Matt A., and Francisco I. Pedraza. 2009. "The Renewal and Persistence of Group Identification in American Politics." Electoral Studies 28 (4): 595-605.

Berry, William D., Matt Golder, and Daniel Milton. 2012. "Improving Tests of Theories Positing Interaction." Journal of Politics 74 (3): 65371.

Betz, Hans-Georg, and Stefan Immerfall, eds. 1998. The New Politics of the Right: Neopopulist Parties and Movements in Established Democracies. New York: St. Martin's Press.

Bilodeau, Antoine, and Nada Fadol. 2011. "The Roots of Contemporary Attitudes toward Immigration in Australia: Contextual and Individuallevel Influences." Ethnic and Racial Studies 34 (6): 1088-1109.

Binder, Norman, J. L. Polinard, and Robert Wrinkle. 1997. "Mexican American and Anglo Attitudes toward Immigration Reform: A View from the Border." Social Science Quarterly 78 (2): 324-37.

Blackwell, Matthew, Stefano Iacus, Gary King, and Giuseppe Porro. 2009. "CEM: Coarsened Exact Matching in Stata." Stata Journal 9 (4): 52446.

Bloemraad, Irene. 2006. "Becoming a Citizen in the United States and Canada: Structured Mobilization and Immigrant Political Incorporation." Social Forces 85 (2): 667-95.

Branton, Regina. 2007. "Latino Attitudes towards Various Areas of Public Policy" Political Research Quarterly 60 (2): 293-303.

Brubaker, Rogers. 1992. Citizenship and Nationhood in France and Germany. Cambridge, MA: Harvard University Press.

Bueker, Catherine Simpson. 2005. "Political Incorporation among Immigrants from Ten Areas of Origin: The Persistence of Source Country Effects." International Migration Review 39 (1): 103-40.

Carle, Adam C. 2009. "Fitting Multilevel Models in Complex Survey Data with Design Weights: Recommendations." BMC Medical Research Methodology 9 (49): 1-13.

Chandler, Charles R., and Yung-mei Tsai. 2001. "Social Factors Influencing Immigration Attitudes: An Analysis of Data from the General Social Survey." Social Science Journal 38 (2): 177-88.

Citrin, Jack, Donald P. Green, Christopher Muste, and Cara Wong. 1997. "Public Opinion toward Immigration Reform: the Role of Economic Motivations." Journal of Politics 59 (3): 858-81.

Citrin, Jack, and John Sides. 2008. "Immigration and the Imagined Community in Europe and the United States." Political Studies 56: 33-56.

de Haas, Hein. 2007. "Turning the Tide? Why Development Will Not Stop Migration." Development and Change 38 (5): 819-41.

DeSipio, Louis. 1987. "Social Science Literature and the Naturalization Process." International Migration Review 21 (2): 390-405.

Esses, Victoria M., John F. Dovidio, Lynne M. Jackson, and Tamara L. Armstrong. 2001. "The Immigration Dilemma: The Role of Perceived Group Competition, Ethnic Prejudice, and National Identity." Journal of Social Issues 57 (3): 389-412.

Festinger, Leon. 1957. A Theory of Cognitive Dissonance. Stanford, CA: Stanford University Press.

Fetzer, Joel S. 2000. Public Attitudes toward Immigration in the United States, France, and Germany. New York: Cambridge University Press.

Franchino, Fabio. 2009. "Perspectives on European Immigration Policies." European Union Politics 10 (3): 403-20.

Freeman, Gary P. 1995. "Modes of Immigration Politics in Liberal Democratic States." International Migration Review 29 (4): 881-902.

Garcia, John. 1981. "Political Integration of Mexican Immigrants: Exploration into the Naturalization Process." International Migration Review 15 (4): 608-25.

Grebler, Leo. 1966. "The Naturalization of Mexican Immigrants in the United States." International Migration Review 1 (1): 17-32.
Hainmueller, Jens, and Dominik Hangartner. 2013. "Who Gets a Swiss Passport? A Natural Experiment in Immigrant Discrimination." American Political Science Review 107 (1): 159-87.

Hainmueller, Jens, and Michael J. Hiscox. 2007. "Educated Preferences: Explaining Attitudes toward Immigration in Europe." International Organization 61 (2): 399-442.

Hainmueller, Jens, and Daniel J. Hopkins. 2014. "Public Attitudes toward Immigration." Annual Review of Political Science 17: 1-25.

Hix, Simon, and Abdul Noury. 2007. "Politics, Not Economic Interests: Determinants of Migration Policy in the European Union." International Migration Review 41 (1): 182-205.

Ho, Daniel E., Kosuke Imai, Gary King, and Elisabeth A. Stuart. 2007. "Matching as Nonparametric Pre-processing for Reducing Model Dependence in Parametric Causal Inference." Political Analysis 15 (3): 199-236.

Hood, M.V., III, Irwin Morris, and Kurt Shirkey. 1997. “iQuedate o Vente!: Uncovering the Determinants of Hispanic Public Opinion toward Immigration." Political Research Quarterly 50 (3): 627-47.

Howard, Marc Morjé. 2009. The Politics of Citizenship in Europe. Cambridge: Cambridge University Press.

Iacus, Stefano M., Gary King, and Giuseppe Porro. 2011. "Multivariate Matching Methods that are Monotonic Imbalance Bounding." Journal of the American Statistical Association 106 (493): 345-61.

Iacus, Stefano M., Gary King, and Giuseppe Porro. 2012. "Causal Inferences without Balance Checking: Coarsened Exact Matching." Political Analysis 20 (1): 1-24.

Jones-Correa, Michael. 1998. Between Two Nations: the Political Predicament of Latinos in New York City. Ithaca, NY: Cornell University Press.

Jones-Correa, Michael. 2001. "Under Two Flags: Dual Nationality in Latin America and Its Consequences for Naturalization in the United States." International Migration Review 35 (4): 997-1029.

Joppke, Christian. 1998. "Why Liberal States Accept Unwanted Immigration.” World Politics 50 (2): 266-93.

Jowell, Roger, Caroline Roberts, Rory Fitzgerald, and Eva Gillian. 2007. Measuring Attitudes Cross-nationally: Lessons from the European Social Survey. London: Sage.

Just, Aida, and Christopher J. Anderson. 2012. "Immigrants, Citizenship, and Political Action." British Journal of Political Science 42 (3): 481509.

Kittilson, Miki Caul. 2009. "Research Resources in Comparative Political Behavior." In The Oxford Handbook of Political Behavior, eds. Russell J. Dalton and Hans-Dieter Klingemann. Oxford: Oxford University Press, 865-95.

Maio, Gregory R., Victoria M. Esses, and David W. Bell. 1994. "The Formation of Attitudes toward New Immigrant Groups." Journal of Applied Social Psychology 24 (19): 1762-76.

Mayda, Anna Maria. 2006. "Who is against Immigration? A CrossCountry Investigation of Individual Attitudes toward Immigrants." Review of Economics and Statistics 88 (3): 510-30.

McLaren, Lauren M. 2003. "Anti-immigrant Prejudice in Europe: Contact, Threat Perception, and Preferences for the Exclusion of Immigrants." Social Forces 81 (3): 909-36.

Meuleman, Bart, Eldad Davidov, and Jaak Billiet. 2009. "Changing Attitudes toward Immigration in Europe, 2002-2007: A Dynamic Group Conflict Theory Approach.” Social Science Research 38 (2): 352-65.

Miller, Lawrence, Jerry Polinard, and Robert Wrinkle. 1984. "Attitudes toward Undocumented Workers: The Mexican American Perspective." Social Science Quarterly 65 (2): 482-94.

Money, Jeannette. 1999. Fences and Neighbors: the Political Geography of Immigration Control. Ithaca, NY: Cornell University Press. 
Mughan, Anthony, and Pamela Paxton. 2006. "Anti-immigrant Sentiment, Policy Preferences and Populist Party Voting in Australia." British Journal of Political Science 36 (2): 341-58.

Munck, Ronaldo. 2008. "Globalization, Governance and Migration: an Introduction." Third World Quarterly 29 (7): 1227-46.

Oliver, J. Eric, and Janelle Wong. 2003. "Intergroup Prejudice in Multiethnic Settings." American Journal of Political Science 47 (4): 56782.

Polinard, Jerry, Robert Wrinkle, and Rodolfo de la Garza. 1984. "Attitudes of Mexican Americans toward Irregular Mexican Immigration.” International Migration Review 18 (3): 782-899.

Portes, Alejandro, and John Curtis. 1987. "Changing Flags: Naturalization and its Determinants among Mexican Immigrants." International Migration Review 21 (2): 352-71.

Portes, Alejandro, and Rubén G. Rumbaut. 2001. Legacies: The Story of the Immigrant Second Generation. Berkeley: University of California Press.

Portes, Alejandro, and Rubén G. Rumbaut. 2006. Immigrant America: A Portrait. $3^{\text {rd }}$ ed. Berkley: University of California Press.

Portes, Alejandro, and Min Zhou. 1993. "The New Second Generation: Segmented Assimilation and Its Variants." Annals of the American Academy of Political and Social Science 530: 74-96.

Quillian, Lincoln. 1995. "Prejudice as a Response to Perceived Group Threat: Population Composition and Anti-immigrant and Racial Prejudice in Europe." American Sociological Review 60 (4): 586-611.

Sanchez, Gabriel. R., and Natalie Masuoka. 2010. "Brown-Utility Heuristic? The Presence and Contributing Factors of Latino Linked Fate." Hispanic Journal of Behavioral Sciences 32 (4): 519-31.

Scheve, Kenneth F., and Matthew J. Slaughter. 2001. "Labor Market Competition and Individual Preferences over Immigration Policy." Review of Economics and Statistics 83 (1): 133-45.

Schildkraut, Deborah J. 2013. "The Complicated Constituency: A Study of Immigrant Opinions about Political Representation.” Politics, Groups, and Identities 1 (1): 26-47.

Semyonov, Moshe, Rebeca Rijman, and Anastasia Gorodzeisky. 2006. "The Rise of Anti-Foreigner Sentiment in European Societies, 19882000." American Sociological Review 71 (3): 426-49.
Sides, John, and Jack Citrin. 2007. "European Opinion about Immigration: The Role of Identities, Interests and Information." British Journal of Political Science 37 (3): 477-504.

Sniderman, Paul M., Louk Hagendoorn, and Markus Prior. 2004. "Predisposing Factors and Situational Triggers: Exclusionary Reactions to Immigrant Minorities." American Political Science Review 98 (1): 35-49.

Snijders, Tom A.B., and Roel Bosker. 1999. Multilevel Analysis: An Introduction to Basic and Advanced Multilevel Modeling. Thousand Oaks, CA: Sage.

Sonenshein, Raphael. 2003. "The Prospects for Multiracial Coalitions: Lessons from America's Three Largest Cities." In Racial Politics in American Cities ( $3^{\text {rd }}$ ed.), eds. Rufus Browning, Dale Rogers Marshall, and David Tabb. New York: Longman, 333-56.

Steenbergen, Marco R., and Bradford S. Jones. 2002. "Modeling Multilevel Data Structures." American Journal of Political Science 46 (1): 218-37.

Stephan, Walter G., C. Lausanne Renfro, Victoria M. Esses, Cookie White Stephan, Tim Martin. 2005. "The Effects of Feeling Threatened on Attitudes toward Immigrants." International Journal of Intercultural Relations 29 (1): 1-19.

Stuart, Elizabeth A. 2010. "Matching Methods for Causal Inference: A Review and a Look Forward." Statistical Science 25 (1): 1-21.

Weil, Patrick. 2001. "Access to Citizenship: a Comparison of Twenty Five Nationality Laws.” In Citizenship Today: Global Perspectives and Practices, eds. T. Alexander Aleinikoff and Douglas Klusmeyer. Washington, DC: Carnegie Endowment for International Peace, 17-35.

Wilkes, Rima, Neil Guppy, and Lily Farris. 2008. "'No Thanks, We're Full': Individual Characteristics, National Context, and Changing Attitudes toward Immigration." International Migration Review 42 (2): 302-29.

Wong, Janelle, and Adrian D. Pantoja. 2009. "In Pursuit of Inclusion: Citizenship Acquisition among Asian Immigrants." In Bringing Outsiders In: Transatlantic Perspectives on Immigrant Political Incorporation, eds. Jennifer L. Hochschild and John H. Mollenkopf. Ithaca, NY: Cornell University Press, 260-76.

World Bank. 2013. World Development Indicators (WDI). Online edition. Washington, DC: World Bank.

Yang, Philip Q. 1994. "Explaining Immigrant Naturalization.” International Migration Review 28 (3): 449-77. 